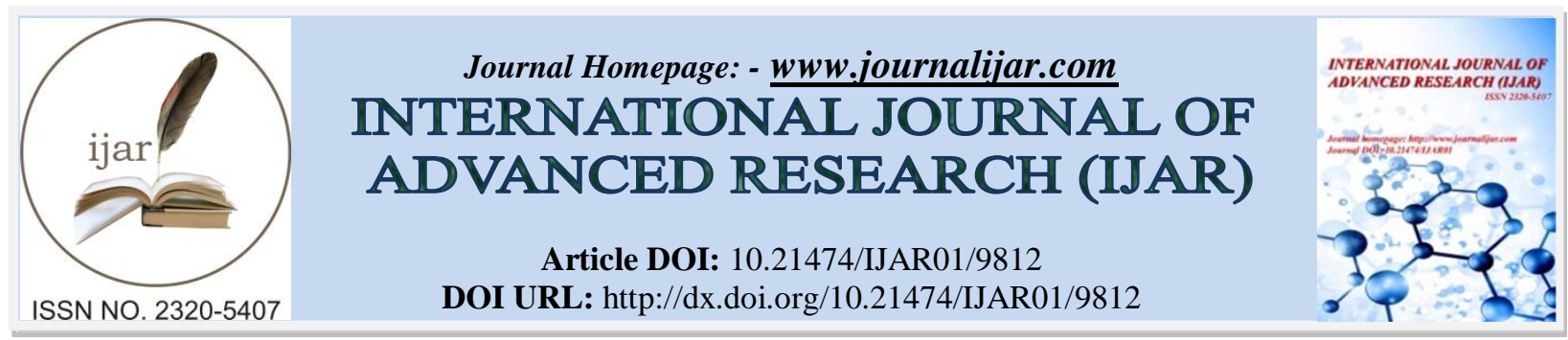

RESEARCH ARTICLE

\title{
COMPARATIVE EFFECTIVENESS OF FRESH LEAVES AND LEAVES POWDER OF SPONDIAS MOMBIN ON MILK PRODUCTION OF DJALLONKE EWES AND WEIGHT GROWTH OF THEIRS LAMBS IN SOUTHERN BENIN.
}

\section{G. Akouedegni ${ }^{1}$, P.V Houndonougbo ${ }^{2}$, A. D. Adenile ${ }^{1}$, O.G. Allowanou ${ }^{1}$ and M. S. Hounzangbé-Adoté ${ }^{1}$.}

1. Laboratory of Ethnopharmacology and Animal Health, Animal Production Department, Faculty of Agricultural Sciences, University of Abomey-Calavi, 01 BP 526, Cotonou, Benin.

2. Laboratoire de Recherches Avicoles et de Zoo Economie 03 BP 2819 Cotonou-Benin.

\section{Manuscript Info}

(.........................

Manuscript History

Received: 04 August 2019

Final Accepted: 06 September 2019

Published: October 2019

Key words:-

Djallonké sheep, galactogenic plants, Spondias mombin, ethnoveterinary, Republic of Benin.

\section{Abstract}

This study was conducted in Republic of Benin to compare the effectiveness of two forms (powder and fresh leaves) of Spondias mombin on the milk production of the Djallonke ewes as well as weight gains of theirs lambs. The experimental part involved 18 lactating ewes divided into three homogeneous groups of 6 animals each that received fresh leaves and powder of leaves of Spondias mombin. The results of experimental study showed that fresh leaves of $S$. mombin improved significantly the milk production of ewes $(109.97 \mathrm{~g}$ VS $96.30 \mathrm{~g}$ and 103.94) and weight gain of lambs (ADG: $107.73 \mathrm{~g} /$ day VS $58.50 \mathrm{~g} / \mathrm{day}$ and $85.33 \mathrm{~g} / \mathrm{day}$ ). The powder of leaves of $S$. mombin had less effect on milk production or on the growth of lambs compared to the fresh group, but had more effect compared to the control group. Treatments based on $S$. mombin had no effect on the variation of body weight of ewes during lactation ( $\mathrm{p}>0.05)$. Also, the leaves of Spondias mombin had no significant effect on $\mathrm{pH}$, dry matter content, ash content, protein and milk fat $(\mathrm{p}>0.05)$. The leaves of $S$. mombin can be a best source of plant drug to increase the milk production on african livestock for malnutrition reduction.

Copy Right, IJAR, 2019,. All rights reserved.

\section{Introduction:-}

Medicinal plants have long been used for the treatment of both diseases in humans and animals (Osai, 1998). Today, more than $80 \%$ of the West African population depends on traditional medicine for the treatment of illnesses (Who, 2002). With regards to the richness and diversity of the African flora, the use of herbal medicine in Africa is more than a necessity. It is an alternative to modern medicine which is sometimes expensive and inaccessible to all population groups. Among the most commonly used medicinal plants, are those with galactogenic properties. These are plants that according to Bognounou and Guinko (1979), are supposed to be able to induce and stimulate lactation or improve the quality of milk. Spondias mombin Linn is a fructiferous tree that all parts are a potential source of highly nutritious feed stuff and phytomedicine. All parts of the tree are ethnopharmacologically important. In a recent review, Ayoka et al., (2008) reported several activities that have been associated with the plant extracts. Some reported pharmacological activities include antibacterial (Corthout et al., 1994), antiviral (Corthout et al., 1992), anti-microbial (Abo et al., 1999), anti-malarial (Carabalo et al., 2004), anti-helmintic (Ademola et al., 2005), 
molluscicidal (Corthout et al., 1994), anti-diarrhoea (Akubue et al., 1983), antiinflammation (Abad et al., 1996), haemostatic (Kone-Bamba et al., 1987), abortifacient (Offiah and Anyanwu, 1989), purgative (Akubue et al., 1983), hypnotic (Ayoka et al., 2005). In Republic of Benin, ethno botanical survey of traditional healers recommends Spondias mombin to have lactogenic activity (Akouedegni, 2013). Igwe (2010) and Akouedegni (2012, 2013) proved lactogenic activity in the ewes treated with fresh leaves of Spondias mombin. This tradition of old is found almost identical to itself and no consistent application in veterinary medicine has been established to our knowledge to date.

To improve the weight gain of pre-weaning lambs, a trial was conducted to compare the effect of leaves powder and fresh leaves of Spondias mombin on ewes milk production and weight gain of theirs lambs.

\section{Materials And Methods:- \\ Study environment:}

The Sheep Research Center of Faculty of Agronomy Sciences is located in the University of Abomey-Calavi in the town of Abomey Calavi near Cotonou. The climate is of guinean type with two dry seasons (from November up to Match, July to September) and two rainy.

\section{Powder obtainment:}

The fresh leaves of $S$. mombin are harvested, dried in the room at $22^{\circ} \mathrm{C}$ and then processed into powder using electric grinder. The dose of powder of plant (23.5g/ewe/day) administered is based on the quantity of leaves (100 $\mathrm{g}$ of fresh leaves) used by traditional healers in treatment the milk production deficiencies (Akouedegni, 2013).

\section{Management of animals:}

The Djallonke ewes of a lambing rank of 2, body weight ranging from $16.5 \pm 1.05 \mathrm{~kg}$ were used in this trial that lasted four months. They were regularly vaccinated against the small ruminant plague and treated against ectoparasites and gastro-intestinal strongyles. After parturition, 18 Djallonke ewes in lactation were selected and randomly divided into 3 groups of 6 animals each. During the first three days of lactation, each ewe receives the fresh leaves and the powder of leaves early in the morning before leaving for grazing.

1. Control group: without treatment

2. Group Fresh: receiving $100 \mathrm{~g}$ of fresh leaves of $S$. mombin per ewe for 3 days at the beginning of lactation.

3. Group Powder: receiving $23.5 \mathrm{~g}$ of powder of $S$. mombin 'leaves per ewe for 3 days at the beginning of lactation.

The animals were conducted on artificial or improved pasture consisting of C1 Panicum maximum, Brachiaria ruziziensis, Andropogon gayanus, Aeschynomene histrix and Cajanus cajan from 11 AM to 17 PM (for 6h).The ewes received extra cotton oil cake protein of $300 \mathrm{~g}$ per day and per animal. Occasionally by-products such as corn, rice straw and groundnut hum were given to them. They also received mineral supplements in the form of licks and water ad libitum throughout the test period.

\section{Data collection:}

For three months, milk production of ewes was estimated once every two weeks using a weigh suckle weigh (WSW) method (WSW: weighing before and after suckling). The lambs were isolated from their mothers at $18 \mathrm{~h}$ pm. The next morning, the lambs were weighed and then returned to their mothers and allowed to feed for $1 \mathrm{~h}$. After feeding, the lambs were reweighed anew. The lambs were then left to the pens and the ewes were then sent to pasture. Back from the pasture, the WSW method was used again to assess the amount of milk suckled by the lamb during the day. The sum of the first and second daily milk suckled gave an estimate of the amount of milk suckled per day per lamb and the total milk production of individual lactations was calculated from birth to weaning.

The body weight of lambs was followed by weighing. The birth weight of lambs was recorded. Every two weeks, the lambs were weighed before feeding in the morning. Average daily gain (ADG) of lambs was calculated to compare the growth of lambs between groups. The body weight of ewes was also measured once a month.

\section{Statistical analyzes:-}

The means and standard errors of the means of milk production, prolactin level as well as those of ADG were determined. Statistical analysis of the differences between mean values obtained for treatments was performed using 
Minitab. Data were subjected to one way analysis of variance (ANOVA) followed by Tukey- Kramer multiple comparison test. In all cases, $\mathrm{p}$ values $<0.05$ were regarded as statistical significance.

\section{Results:-}

\section{Milk production:}

From the first week up to the ninth week of lactation, the lactation curves (Fig 1) showed that ewes that received the fresh leaves and powder of leaves of $S$. mombin produced more milk than control group. From the ninth week to the end of lactation, the daily milk production is similar in all groups (Fig 1). This is evident on the lactation table of three groups (Table1). The daily milk production of the third week lactation was significantly higher $(\mathrm{p}<0.05)$ in the ewes of Group Fresh and Group Powder than group Control. Likewise, these parameters were significantly higher in the fresh group than the powder group. The daily milk production of the ninth week lactation, the average daily milk production for all lactation duration, the total milk production were not different between groups Powder and fresh ( $\mathrm{p}>0.05$ ). But, the average daily milk production for all lactation duration and the total milk production were significantly higher in the ewes for the fresh group compared to control group $(p<0.05)$.

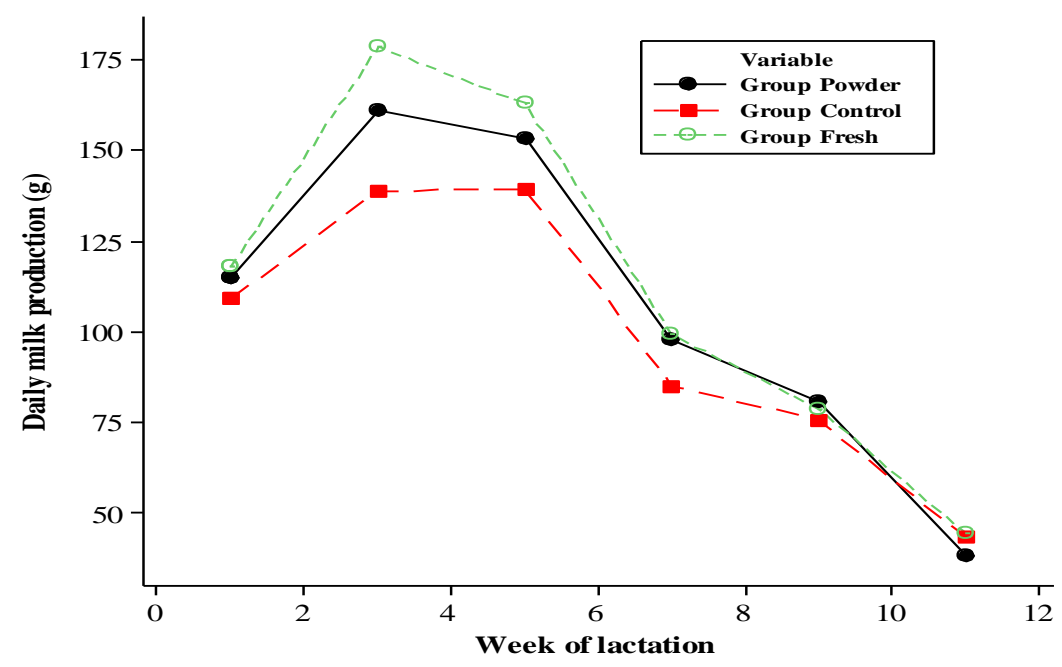

Figure 1:-Daily milk production according to week of lactation and treatment.

Table 1:-Milk production (g) according to treatments.

\begin{tabular}{|l|r|r|r|}
\hline Parameter & Group Fresh & Group Control & Group Powder \\
& & & \\
\hline Third week lactation $(\mathrm{g})$ & $181.15 \pm 23.27 \mathrm{~b}$ & $138.80 \pm 17.78 \mathrm{a}$ & $169.02 \pm 21.3 \mathrm{c}$ \\
\hline Ninth week lactation $(\mathrm{g})$ & $53.32 \pm 13.62 \mathrm{a}$ & $48.61 \pm 12.5 \mathrm{a}$ & $45.32 \pm 24.46 \mathrm{a}$ \\
\hline Average Daily milk production $(\mathrm{g})$ & $109.97 \pm 9.20 \mathrm{a}$ & $96.30 \pm 4.45 \mathrm{~b}$ & $103.94 \pm 7.38 \mathrm{ab}$ \\
\hline Total milk production $(\mathrm{g})$ & $715.34 \pm 20.91 \mathrm{a}$ & $650.30 \pm 26.37 \mathrm{~b}$ & $679.18 \pm 20.8 \mathrm{ab}$ \\
\hline
\end{tabular}

a, b, c:Means with different superscript letters on the same row differ significantly. $* \mathrm{P}<0.05$

\section{Weight performance:}

The body weight of lambs increased gradually during the first half and was virtually identical in all groups (Figure 2). After the first two weeks, this increase became higher in the fresh group and powder group than the control group. The analysis of variance (Table 2) showed that average daily gain (ADG) of the lambs in 15 - 30 days, 30 45 days and 60 - 75 days were not different between the powder group and control group but significantly higher in the lambs for the fresh group $(\mathrm{p}<0.05)$. The ADG of the lambs in $45-60$ days, 75 - 90 days were not different between groups. In the mean-time, The ADG of the lamb in $0-15$ days was significantly different between all 
treatments compared two and two $(\mathrm{p}<0.05)$. Also the treatments had no effect on initial and final body weight of ewe ( $>>0.05)$ (Table 2).

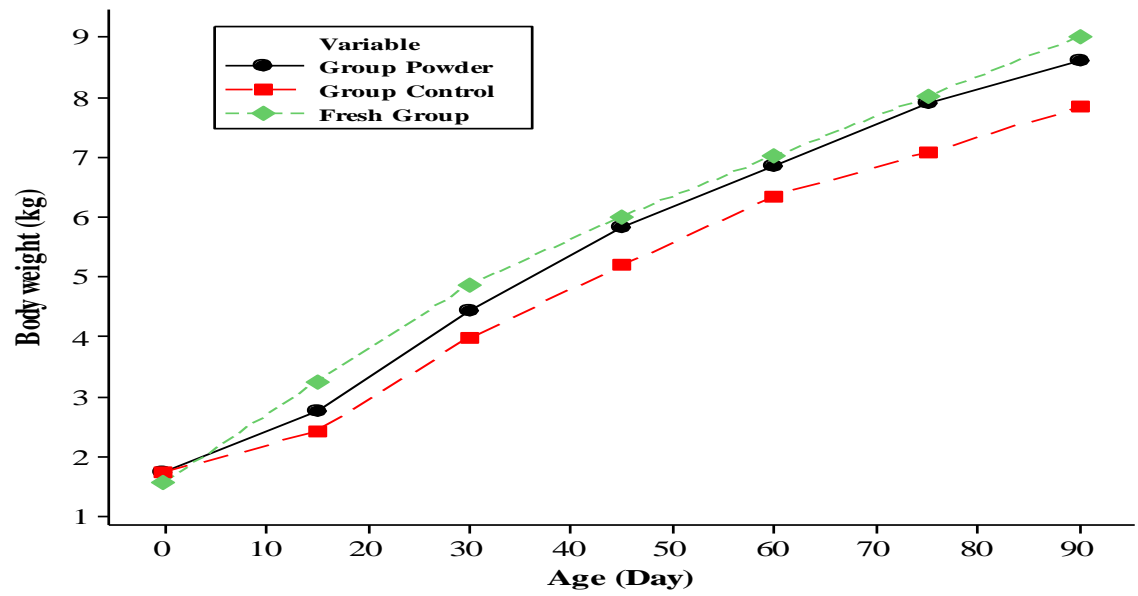

Figure 2:-Lamb body weight according to age and treatments.

Table 2:-Average Daily Gain (ADG) g/day of lambs according to the treatments

\begin{tabular}{|l|l|l|l|}
\hline Parameters & \multicolumn{1}{|c|}{ Group Fresh } & Group Control & Group Powder \\
\hline ADG 0 - 15days & $107.73 \pm 10.81 \mathrm{a}$ & $58.50 \pm 10.95 \mathrm{~b}$ & $85.33 \pm 9.89 \mathrm{c}$ \\
\hline ADG 15 - 30 days & $112.67 \pm 13.82 \mathrm{a}$ & $77.13 \pm 9.83 \mathrm{~b}$ & $94.87 \pm 5.06 \mathrm{ab}$ \\
\hline ADG 30 - 45 days & $101.33 \pm 8.03 \mathrm{a}$ & $79.51 \pm 4.44 \mathrm{~b}$ & $87.33 \pm 7.96 \mathrm{ab}$ \\
\hline ADG 45 - 60 days & $88.86 \pm 6.33 \mathrm{a}$ & $76.20 \pm 5.83 \mathrm{a}$ & $81.20 \pm 11.94 \mathrm{a}$ \\
\hline ADG 60 - 75 days & $75.53 \pm 2.37 \mathrm{a}$ & $54.60 \pm 13.77 \mathrm{~b}$ & $70.66 \pm 9.87 \mathrm{ab}$ \\
\hline ADG 75 - 90 days & $53.53 \pm 4.02 \mathrm{a}$ & $46.53 \pm 5.41 \mathrm{a}$ & $48.86 \pm 5.03 \mathrm{a}$ \\
\hline Ewes Body weight $(\mathrm{kg}$ & & & \\
\hline First day of lactation & $16.64 \pm 0.75 \mathrm{a}$ & $16.68 \pm 0,98 \mathrm{a}$ & $16.74 \pm 0.76 \mathrm{a}$ \\
\hline 90 days of lactation & $17.32 \pm 0.67 \mathrm{a}$ & $17.49 \pm 0.89 \mathrm{a}$ & $17.24 \pm 0.48 \mathrm{a}$ \\
\hline
\end{tabular}

$\mathrm{a}, \mathrm{b}, \mathrm{c}=$ Means with different superscript letters on the same row differ significantly. $* \mathrm{P}<0.05$

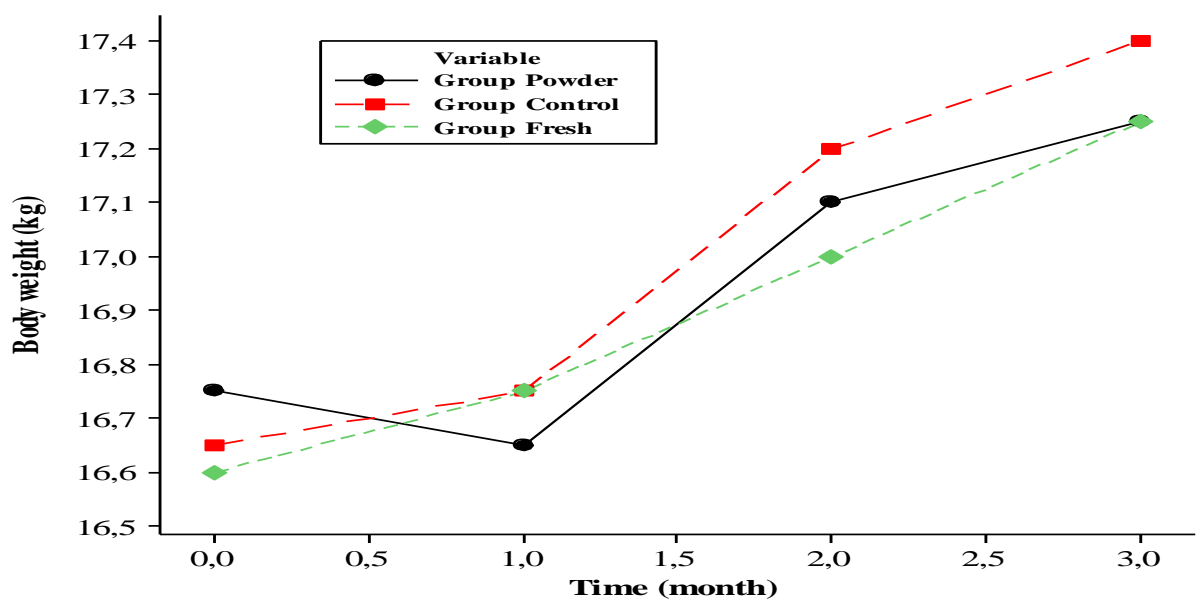

\section{Milk physico-chemical composition}

The $\mathrm{pH}$ of milk found no difference in the three groups making it statistically insignificant (p > 0.05) (Table 3). Regarding the chemical composition, it was noticed that the milk of ewes in control group contained less water compared to groups Fresh and Powder but without significantly difference ( $p>0.05)$. The ash content, protein and fat were not significantly different between the groups $(\mathrm{p}>0.05)$ (Table 3$)$. 
Table 3:-Milk physico-chemical composition

\begin{tabular}{|l|c|c|c|}
\hline Parameters & Group Fresh & Group Control & Group Powder \\
\hline $\mathrm{pH}$ & $6.92 \pm 0.04 \mathrm{a}$ & $6.94 \pm 0.04 \mathrm{a}$ & $6.92 \pm 0.07 \mathrm{a}$ \\
\hline Total Solid TS (\%) & $15.22 \pm 0.16 \mathrm{a}$ & $15.57 \pm 0.26 \mathrm{a}$ & $15.35 \pm 0.29 \mathrm{a}$ \\
\hline Ash content (\%TS) & $2.03 \pm 0.03 \mathrm{a}$ & $2.04 \pm 0.05 \mathrm{a}$ & $2.06 \pm 0.6 \mathrm{a}$ \\
\hline Protein (\%TS) & $5.17 \pm 0.02 \mathrm{a}$ & $5.19 \pm 0.05 \mathrm{a}$ & $5.25 \pm 0.15 \mathrm{a}$ \\
\hline Fat (\%TS) & $6.23 \pm 0.13 \mathrm{a}$ & $6.40 \pm 0.15 \mathrm{a}$ & $6.20 \pm 0.23 \mathrm{a}$ \\
\hline
\end{tabular}

$\mathrm{a}, \mathrm{b}, \mathrm{c}=$ Means with different superscript letters on the same row differ significantly. $* \mathrm{P}<0.05$

\section{Discussion:-}

The floristic and ethnobotanic aspects of lactogenic plants have been studied extensively (Bailey and Day, 2004; Wynn and Fougere, 2007); however, little is known about their biological activities. In this study Spondias mombin was investigated for its activity on milk production. The results obtained on milk production indicate that the leaves of Spondias mombin significantly stimulated milk production in treated ewes compared to control group. The ewes from the Fresh group and the powder group produced more milk than ewes of other Control group. The better production of milk by the groups treated with the Spondias mombin could be due to the action of the lactogenic activity from the leaves of $S$. mombin. In fact, the lactogenic effect of leaves of $S$. mombin has already been tested by Akouedegni $(2012,2013)$ and Oguike (2008). The lactogenic activity of the leaves of $S$. mombin could be related its ability to stimulate the secretion of hormones that promote milk synthesis (Houdebine, 1986), especially the prolactin (Sawadogo, 1987). Prolactin plays a major role in the induction of milk secretion (Sawadogo, 1987) and also appears to be involved in the growth of the mammary gland. Kensinger et al. (1982) observed a positive correlation between level of the prolactin in the blood and the weight of breast tissue. The difference of milk production between fresh group and powder group could be due to nutritive composition of the leaves plant that can vary according to the leave forms.

The lambs of the groups Fresh and Powder had the best weight performance. Also, the best average daily gain was observed with these lambs compared to the Control group. This was due to the greater milk production of the ewes. Indeed, for lambs unable to take solid foods, breast milk is the only source of nutrients (Coulibaly, 1988) and their growth depends on its consumption (Abassa, 1992). This dependence for pre weaning growth of lambs on the ewe milk production was earlier reported by several authors. For example Boujenane (1996) and Amégée (1984) reported a positive correlation $(\mathrm{r}=0.52$ to 0.86$)$ between milk production and lamb growth in the Djallonke sheep. From birth to 90 days of age, ADG ranged from 46.53 to $112.67 \mathrm{~g}$ /day between groups. These results are similar to those of Vallerand and Branckaert (1975), Rombaut (1980) and Poivey et al. (1982) who noticed that the ADG of lambs are generally between 50 and $150 \mathrm{~g} /$ day the month following their birth. These gain fell eventually below this level and remain stable at best. Contrary to our results, N'gère (1973) reported that between 0 and 90 days, the daily gain ranged from $115-134 \mathrm{~g}$ /day for single births. This difference could be explained by several factors including the rank of lambing, the birth weight of lambs and experimental conditions.

The $\mathrm{pH}$ of the milk in the three groups is similar. It is noticed that the milk in the control group seems contain less water. This difference can be explained by several factors like genetic factors and the treatments Atti and Rouissi (2003). Others chemical constituents are identical in the three groups and are statistically insignificant. These results are similar to those reported by Rouissi et al. (2007) in an assay where the soybeans were replaced by horse bean in the feed of ewes. The protein content of milk obtained in this study is similar to the one of Adewumi and Olorunnisomo (2009): 5.17 - 5.25\% in WAD ewes. Ekeocha (2012) obtained slightly higher values from fat (7.08\%) and protein $(6.12 \%)$ in WAD ewes. This difference could be explained by feeding regimes, ration components and forage, grain ratios that affected milk composition. 


\section{Conclusion:-}

The effectiveness test of fresh leaves and powder of leaves of Spondias mombin on the Djallonke ewes milk production showed the positive effect of fresh leaves on milk production on the one hand and on the other hand its positive effect on the weight gains of lambs. As a matter of fact, interesting increases in milk production and body weight of lambs belonging to the fresh group that received the fresh leaves of $S$. mombin were observed with the Djallonke sheep. The powder of leaves of S. mombin had less effect on milk production or on the growth of lambs compared to the fresh group.

\section{Acknowledgement:-}

We are grateful to the Ministry of Higher Education and Scientific Research of Benin for its assistance.

\section{References:-}

1. Abad, M.J., Bermejo, P., Carretero, E. and Martinez-Acitores, C. (1996): Anti-inflammatory activity of some medical plant extracts from Venezuela. J Ethnopharmacol, 55 (1): 63-68.

2. Abo, K.A., Ogunleye V.O. and Ashidi, J.S. (1999): Antimicrobial potential of Spondias mombin, Croton zambesicus and Zygotritonia crocea. Phytotherapy Res, 13: 494-497.

3. Ademola, O., Fagemib, O. and Idowu, S.O. (2005): Anthelminthic activity of extract of Spondias mombin against gastrointestinal nematodes of sheep: studies in vitro and in vivo. Trop Anim Health Prod., 37(3): 223235.

4. Adewumi, O.O. and Olorunnisomo, O.A. (2009): Milk yield and milk composition of West African dwarf, Yankasa and crossbred sheep in southwest of Nigeria. Livest. Res. Rural Develop., 21 (3); 29-32.

5. Akouedegni, C.G. et Hounzangbe-Adote, M.S. (2012): Efficacité de poudre de feuilles de Spondias mombin et de Vitellaria paradoxa sur la production laitière des brebis Djallonké et la croissance pondérale des agneaux au Sud Bénin. Journal de Recherche Science Université Lomé (Togo), Série A, 14 (2) : 19-28.

6. Akouedegni, C.G., Adénilé, A.D., Gbégo, I.S. and Hounzangbé-Adoté, M.S. (2013): Efficacité des feuilles de Spondias mombin L. sur la production laitière et la croissance pondérale des ovins Djallonké au Sud-Bénin. Annales des Sciences Agronomiques, 17 (2) : 137-148.

7. Akubue, P.I., Mittal, G.C. and Aguwa, C.N. (1983): Preliminary pharmacological study of some Nigerian medicinal plants. J Ethnopharmacol, $8: 53-63$.

8. Amegee, Y. (1984): Le mouton de vogan (croisé Djallonké x Sahélien) au Togo : I. Production lactée et ses relations avec la croissance des agneaux. Revue Elev. Méd. Vét. Pays Trop., 37(1): 82 - 90.

9. Attin Rouissi, H. (2003): La production de lait de brebis Sicilo Sarde: Effet de la nature de pâturage et du niveau de la complémentation. Annales de l'I.N.R.A de Tunisie., 76:209-224.

10. Ayoka, A.O., Akomolafe, R.O., Akinsomisoye, O.S. and Ukponmwan, O.E. (2008): Medicinal and Economic value of Spondias mombin. African Journal of Biomedicinal Research, 11: 129-136.

11. Bailey, C.J. and Day, C. (2004): Metformin: Its botanical background. Practical Diabetes Inter: 115-117.

12. Bognounou, O. and Guinko, S. (1979): Plantes lactogènes Enquêtes ethnobotaniques en pays BISSA et BWABA (Burkinafaso). Colloque du CAMES, Abidjan.

13. Boujenane, I., Berrada, D., Mihi, S. and Jamai, M. (1996) : Production laitière des brebis de races Timahdite, Sardi et Béni Guil en race pure et en croisement. Actes Inst. Agron. Veto (Maroc), 16 (3): 11 - 18.

14. Caraballo, A., Caraballo, B. and Rodriguez-Acosta, A. (2004): Preliminary assessment of medicinal plants used as antimalarials in the south-eastern Venezuelan Amazon. Revista-da-Scciedade-Brasileira-de-MedicnaTropical., 37(2): 186-188.

15. Corthout, J., Pieters, L.A., Claeys, M., Vanden-Berghe, D.A. and Viletinck, A.J. (1994): Antibacterial and molluscicidal phenolic acid from Spondias mombin. Planta Medica, 60: 460-463.

16. Corthout, J., Pieters, L.A., Claeys, M., Vanden-Berghe, D.A. and Viletinck, A.J. (1992): Antiviral caffeoyl: esters from Spondias mombin. Phytochem, 31: 79-81.

17. Coulibaly, N.D. (1988): Sélection sur les ovins de race Djallonké type Mossi au Centre d'Appui Zootechnique de Ouahigouya, Province du Yatanga (Burkina Faso). Thèse Doct. Veto Dakar. EISMV. N³7. 93p.

18. Ekeocha, A.H. (2012): Leaf Meal Based Diets during Early and Late Lactation, J Rec Adv Agri, 1(2):43-49.

19. Houdebine, L.M. (1986): Contrôle hormonal du développement de l'activité de la glande mammaire. Reprod. Nutr. Dévelop, 26: 523 - 541.

20. Igwe, C.U., Onyeze, G.O.C., Onwuliri, V.A., Osuagwu, C.G. and Ojiako, A.O. (2010): Evaluation of the Chemical Compositions of the Leaf of Spondias Mombin Linn from Nigeria; Australian Journal of Basic and Applied Sciences, 4(5): 706-710. 
21. Kensinger, R.S., Collier, W., Bazer, F.W., Ducsay, C.A. and Becker, H.N. (1982): Nucleic acid, metabolic and histological changes in gilt mammary tissue during pregnancy and lactogenesis. J. Anim. Sci., 54: 1297 - 1308.

22. Kone-Bamba, D., Pelissier, Y., Ozoukou, Z.F. and Kouao, D. (1987) : A study of the haemostatic activity of fifteen medicinal plants of the traditional pharmacopoeia of Ivory Coast. Plantes-Medicinales-et-Phytotherapie, 21(2): 122-130.

23. N'gère, L.O. (1973): Size and growth rate of the West African dwarf sheep and new breed, the Nungua black head of Ghana. Ghana J. Agric. Sci., 6: 113 - 117.

24. Offiah, V.N. and Anyanwu, I.I. (1989): Abortifacient activity of an aqueous extract of Spondias mombin leaves. J Ethnopharmacol, 26: 317-320.

25. Oguike, M.A. and Udeh, N. A. (2008): Influence of ethnoveterinary plant, Spondias mombin L. on partial daily milk yield (PDM): Hematology and serum biochemistry of lactating West Africa Dwarf ewes. Journal of Animal and Veterinary Advances, 7(5): 585 - 588.

26. Osai, V. (1998): The transition challenges of herbal drug. Nigerian Journal of Natural Products and Medicine, 2: $16-18$.

27. Poivey, J.P., Landais, E. and Berger, Y. (1982) : Etude et amélioration génétique de la croissance des Djallonké. Résultats obtenus au Centre de Recherches Zootechniques de Bouaké (Côte-d'Ivoire). Revue Elev. Méd. Vét. Pays Trop., 35: 421 - 433.

28. Rombault, D. (1980) : Comportement du mouton Djallonké en élevage rationnel. Rev. Elev. Méd. Vét. Pays Trop., 33(4): 427 - 439.

29. Rouissi, H., Rekik, B., Maamouri, O., Kammoun, M. and Ben Gara, A. (2007): Replacing soya by field beans improves milk production and affects milk quality in Sicilo Sarde ewes fed concentrate during the suckling period. 12 th seminar of the FAO-CIHEAM Sub-Network on sheep and goat nutrition.11-13 October, Thessaloniki (Greece), 345p.

30. Sawadogo, L. (1987): Contribution à l'étude des plantes médicinales et de la pharmacopée traditionnelle africaine: cas des plantes lactogènes. Thèse de Doctorat d'Etat des Sciences naturelles. Tours (France). $187 \mathrm{p}$.

31. Vallerand, F. and Branckert, R. (1975): La race ovine Djallonké au Cameroun: Potentialités zootechniques, conditions d'élevage, avenir. Rev Elev. Med. Vet. Pays Trop., 28(4): 523 - 545.

32. WhO. (2002). Traditional medicines strategy 2002-2005. World Health Organization, Geneva; Switzerland.

33. Wynn, S.G. and Fougere, B.J. (2007). Veterinary Herbal Medicine. St. Louis: Mosby Else vier. 